\title{
Isolation and Molecular Identification of Freshwater Microalgae in Maninjau Lake West Sumatra
}

\author{
Zulkarnain Chaidir $^{1}$, Neri Fadjria ${ }^{1,2}$, Armaini $^{1}$ and Rahadian Zainul ${ }^{3}$ \\ ${ }^{1}$ University of Andalas Padang \\ ${ }^{2}$ Akademi Farmasi Dwi Farma Bukittinggi \\ ${ }^{3}$ Universitas Negeri Padang
}

\begin{abstract}
Microalgae are photosynthetic prokaryotic and eukaryotic microorganisms. In this research, isolation of microalgae from Maninjau lake West Sumatra was identified by morphological and molecular identification by PCR using primers for $16 \mathrm{~S}$ rDNA and $18 \mathrm{~S}$ rDNA prokaryotic and eukaryotic microalgae. The results of this study were obtained 3 isolates of microalgae that can be isolated from Maninjau lake West Sumatra are Scenedesmus (code isolate AUMA-020) with a percent similarity of 95\%, Uncultured cyanobacterium (code isolates AUMA-023) with a percent similarity of $80 \%$ and Limnothrix (code isolates AUMA-019) has a percent similarity of 98\% based on data gene Bank blast results.
\end{abstract}

Keywords: Isolation, Microalgae, Morphological, Molecular, PCR

\section{INTRODUCTION}

Microalgae are plants that are easy to grow throughout the season in Indonesia. Habitat microalgae are generally in the waters and fits perfectly with the geographic Indonesia. Microalgae are not included in the higher plants because they do not have the characteristics and functions of such plants. Microalgae have no roots, stems and leaves [1]. Microalgae are photosynthetic prokaryotic and eukaryotic microorganisms [2] which is the basis or the beginning of the aquatic food chain because of their photosynthetic activity or the called primary producers [3]. The compounds resulting from the process of photosynthesis can be utilized for the benefit of humans, like suplement [4], biofuel [5] and Pharmaceutical [6].

Microalgae are usually referred to as phytoplankton. Based on the size of phytoplankton are grouped in picoplankton $(<2 \mu \mathrm{m})$, nannoplankton $(2-20 \mu \mathrm{m})$, microplankton $(20-200 \mu \mathrm{m})$ and makroplankton $(>200 \mu \mathrm{m})$. In addition to the size, shape and the presence of microalgae waters vary greatly depending on the species mikroalganya. Microalgae have some shapes such as round, elliptical, rectangular, trapezoidal, rod, cylinder, star and form combinations. Microalgae are found in the form of uni non-motile cells (such as Chorella and Selenastum), uni motile cells (Chlamydomonas), a non-motile colonies (Scenedesmus), and motile colonies (Volvox). The shape and size is important in the identification and classification of morphological microalgae. Sequensing microalgae taxonomy is determined by $18 \mathrm{~S}$ ribosomal RNA genes for eukaryotic and prokaryotic 16S ribosomal RNA [7] based on the type of microalgae that have been identified morphologically. Prokaryotic microalgae has two divisions, Cyanophyta and Prochlorophyta while eukaryotic has 9 divisions: glaucophyte, Rhodophyta, heterokont, Haptophyta, Cryptophyta, dinoflagellate, Euglenophyta, Chlorarachniophyta and Chlorophyta [8].

Water resources affect the types of microalgae are grown. Selvarajan et al. (2015) has screened Chlorophyceae strains of microalgae from Soda Lake in Hungary as a biofuel production [9]. Yang et al. (2012) successfully isolate 
strains of microalgae Chlorella sp. C11, C22 Chlamydomonas reinhardtii, Monoraphidium dybowskii C29 and Chlorella sp. HK12 of Hainan Lake in China for the production of biofuels [10]. Isolation of cyanobacteria from the Samuthiram Lake in India is a species Oscillatoria latevns, Phormidium corium, Lyngbya martensiana, Chrooccocus minor and Microcystis aeroginosa antimicrobial activities [11]. West Sumatra has a Maninjau Lake yet examined the types of microalgae that are out of the lake so that the study was conducted isolation of microalgae found in Maninjau Lake West Sumatra and molecularly identified.

\section{MATERIALS AND METHODS}

\section{Materials and Equipment Used}

The materials used in this study are as follows microalgae samples derived from the water of Maninjau Lake, Medium Fuel (NaNO3 (Merck), MgSO4.7H2O (Merck), $\mathrm{NaCl}$ (Merck), $\mathrm{K}_{2} \mathrm{HPO}_{4}$ (Merck), $\mathrm{KH}_{2} \mathrm{PO}_{4}$ (Merck), $\mathrm{CaCl}_{2} \cdot 2 \mathrm{H}_{2} \mathrm{O}$ (Merck), $\mathrm{ZnSO}_{4} \cdot 7 \mathrm{H}_{2} \mathrm{O}$ (Merck), $\mathrm{MnCl}_{2} \cdot 4 \mathrm{H}_{2} \mathrm{O}$ (Merck), $\mathrm{MoO}_{3}$ (Merck), $\mathrm{CoSO}_{4} \cdot 5 \mathrm{H}=\mathrm{O}$ (Merck), $\mathrm{Co}\left(\mathrm{NO}_{3}\right)_{2} \cdot 6 \mathrm{H}_{2} \mathrm{O}$ (Merck), Qiagen kits for the isolation of DNA, loading dye.

The tools used are as follows 30 micron filter plankton net, the light microscope (Olympus CX41), incubators, aerator, autoclave, UV-Vis spectrophotometer (Genesys 20), means of PCR (Polymerase Chain Reaction), electrophoresis apparatus, centrifuges.

\section{Research procedure}

\section{Sampling Microalgae}

Water samples were taken in Lake Maninjau West Sumatra during the day using a plankton net with 30 micron hole size. [12]. Air is taken dikedalaman about $30 \mathrm{~cm}$ below the water surface of the lake and put into bottles that have been sterilized, then given media to cultivate microalgae fuel contained in Maninjau Lake West Sumatra.

\section{Isolation and Purification Microalgae}

Microalgae that has grown in isolation with multilevel dilution technique with microalgae and medium fuel ratio 1: 9 (v / v). Dilution is carried out from $10^{-1}$ to $10^{-9}$ and incubated at a temperature of $27-30^{\circ} \mathrm{C}$. And let it grow microalgae and viewed under a light microscope. To be more pure type of microalgae which can then be isolated microalgae with capillary pipette technique and grown back to cultivation [13].

\section{Morphological Identification of Microalgae}

Morphological Identification of microalgae which has been isolated is done microscopically. Observations were carried out regularly under the microscope to make sure he had learned a single cell.

\section{Molecular identification}

Isolates of microalgae as much as $10 \mathrm{~mL}$ disentrifius $10,000 \mathrm{rpm}$ for 30 minutes, then extracted DNA using Dneasy ${ }^{\circledR}$ plant mini kit (Qiagen, Hilden, Germany). Each extract DNA samples obtained is processed by electrophoresis using BIO-RAD tool and PowerPac Electrophoresis chamber. The results obtained were amplified by PCR using universal primers for regions D1-D2 LSU rDNA. Prokaryotic microalgae using 16S rDNA namely FW1 primer (5'GACGGGTGAGTAATGCCTA-3') and rev1 (5'CACTGGTGTTCCTTCCTATA -3') with about 600-700 bp PCR product. While using $18 \mathrm{~S}$ rDNA of eukaryotic microalgae namely FW1 primer (5'CCTGGTTGATCCTGCCAG -3') and rev1 (5'TTGATCCTTCTGCAGGTTCA -3') with about 1500 bp PCR product. PCR was performed for 35 cycles; initialing $95^{\circ} \mathrm{C}$ for 5 minutes, denaturation at a temperature of $95^{\circ} \mathrm{C}$ for $30 \mathrm{~s}$, annealing at temperatures $56,3^{\circ} \mathrm{C}$ for $45 \mathrm{~s}$, extension at $72^{\circ} \mathrm{C}$ for $30 \mathrm{~s}$, termination at $72^{\circ} \mathrm{C}$ for 5 minutes. PCR products were electrophoresed with $1.5 \%$ agarose, a voltage of 100 volts and a time of 1 hour 30 minutes. DNA was extracted using NucleoSpin ${ }^{\circledR}$ Gel and PCR Clean-up kit [14]. Direct sequencing carried out directly against DNA electrophoresis results. Sequences obtained in Blast data NCBI gene. Sequence alignment of multiple sequences of isolates with species that have similarities done using ClustalX2.1 program. Analysis of distance between species is done by using a program MEGA6.06. Family tree is based on maximum likelihood test.

\section{RESULTS AND DISCUSSION}

samples

In general the temperature of the area of Lake Maninjau between $22^{\circ} \mathrm{C}-31^{\circ} \mathrm{C}$ is located at coordinates $0^{\circ} 19^{\prime} \mathrm{LU}$ $100^{\circ} 12^{\prime} \mathrm{BT} / 0,317^{\circ} \mathrm{LS} 100,2^{\circ} \mathrm{BT}$. Temperature water of Maninjau Lake $30^{\circ} \mathrm{C}$ and $\mathrm{pH} 7$ at 14:00 pm. Water sampling is done during the day meant microalgae rise above the water surface in order to make the process of photosynthesis so that the water samples brought many types of microalgae. 


\section{Morphological Identification Isolation of Microalgae}

Isolation of microalgae carried out with the aim to separate the one species of microalgae to be developed and analyzed further. Before the isolation process, all the equipment and the culture medium should be sterilized. Techniques used in the isolation process that is multilevel dilution technique (dilution) and to facilitate the isolation of single cell microalgae are performed with capillary pipette technique [15]. There are three types of microalgae isolated from the lake Maninjau which isolates AUMA-020, Isolate AUMA-023 and AUMA-019 seen in morphology.

\section{Isolate AUMA-020}

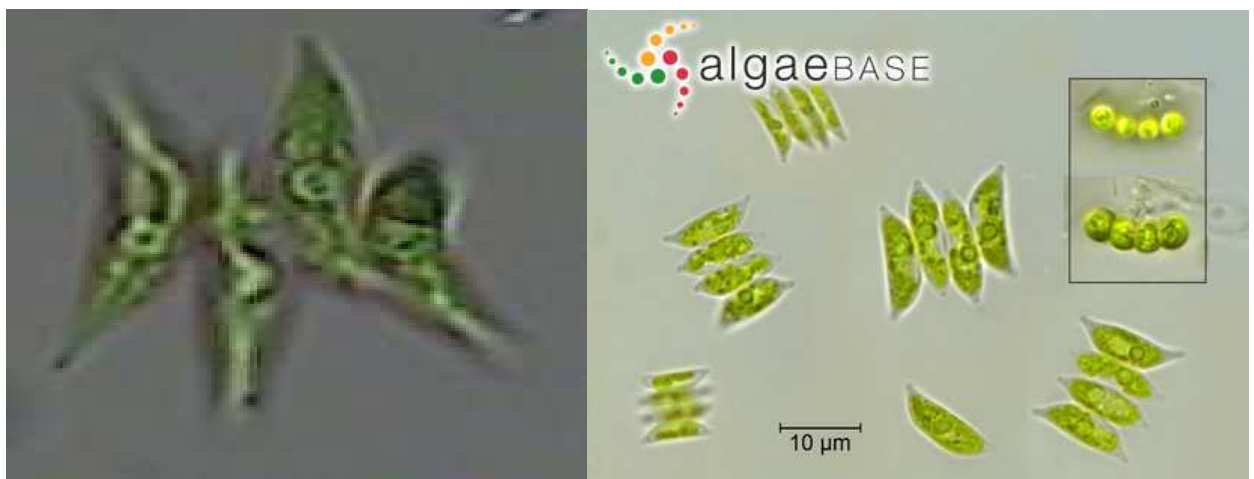

Figure 1. The shape morphology of a) Isolate AUMA-020 b) Scenedesmus (algaeBASE.org)

Viewed in morphology on the image 1.A isolates code AUMA-020 is similar to the type Scenedesmus algaeBASE database of the website. Website algaeBASE.org are clusters microalgae that have been registered from all over the world. Scenedesmus consists of 1 or 2 cells sometimes 3 cells, usually form colonies consisting of 2, 4 or 8 cells can even reach 16 to 32 cells in each colony. Cells cylindrical, oval, round, with the end of the cell is round or tapered. Scenedesmus cells have one nucleus and chloroplast contained one pyrenoid. At the terminal Scenedesmus cells are cells called ornament with spina whose size can reach lengths of up to 20 micrometers [16]. Cellulose is the outer cell wall constituent containing $\alpha-1,4$-glucan. Scenedesmus contain pigment chlorophyll a and $\mathrm{b}$ and carotenoid pigments such as $\alpha-, \beta-, \gamma$-carotene [7]. Scenedesmus included into the division Chlorophyta which is a eukaryotic cell, where the classification of isolates AUMA-020 as follows:

Division: Chlorophyta

Class: Chlorophyceae

Order: Chlorococcales

Family: Scenedesmaceae

Genus: Scenedesmus

\section{Isolat AUMA-023}

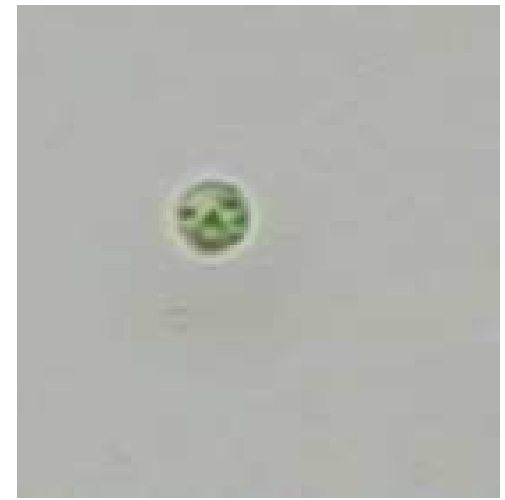

Figure 2. The shape morphology isolates AUMA-023

The second type are isolated from water samples of Maninjau Lake is kind of Prochlorococcus (code isolates AUMA-023) as in figure 2 with the characteristics of the cells are round, unicellular, colonial, green. Genus Prochlorococcus very small size of about $0.5-0.8$ micrometers and pigment chlorophyll a and $\mathrm{b}$ and is the primary 
producer and responsible for the production of oxygen in the world [17]. Other pigments of Prochlorococcus is contained zeaxanthin, $\alpha$-carotene, carotenoids and a small amount of chlorophyll c [18]. Based on the description above, isolates AUMA-023 belonging to the microalgae prokaryotic classification isolates AUMA-023 as follows:

Division: Cyanobacteria

Class: Synechococcales

Order: Synechococcales

Family: Synechococcaeae

Genus: Prochlorococcus

\section{Isolat AUMA-019}

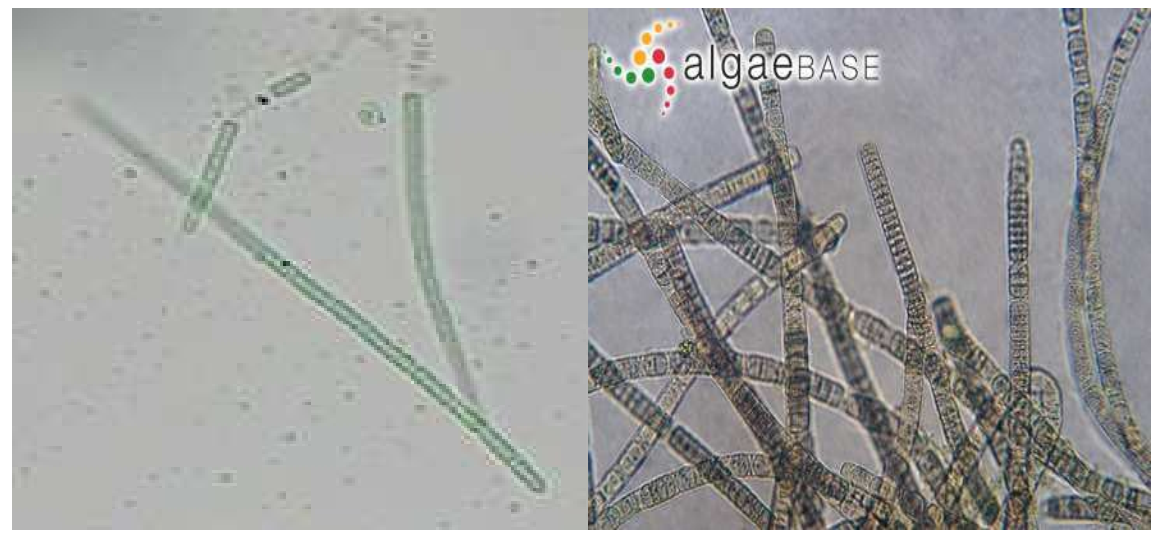

Figure 3. Form a morphology. Isolates AUMA-019, and b. Oscillatoria (algaeBASE.org)

In fig. 3A isolates AUMA-019 shows the type of microalgae Oscillatoria similar to the database of the website algaeBASE. Oscillatoria have characteristics of cylindrical cells, trichomes unbranched, green Tosca (blue-green) and generally long and jointed. Diameter trichomes about 8-30 micrometers or more, and a cell filamentous. Filaments on Oscillatoria very important to differentiate morphology microalgae species are species of Planktothrix, Pseudananabaena and limnothrix. Some species produce toxins such as Oscillatoria neurotoxin (anatoksin) and hepatotoxins (microcystin). Some species Oscillatoria tolerance to organic pollution and nitrogen are high [16]. Oscillatoria not have cell organelles, cell walls containing peptidoglycan-containing pigments carotenoids like zeaxanthin and $\beta$-carotene and chlorophyll pigments [7]. The blue color seen in isolates AUMA-019 is a photosynthetic pigments other so-called C-phycocyanin [19]. AUMA-019 isolates morphology similar to microalgae isolated from palm oil industrial waste that is Uncultured Oscillatoria sp. IPOME-4 [20]. Because Oscillatoria belong to the phylum Cyanophyta, thus isolates AUMA-019 is a prokaryotic microalgae. From these results isolates AUMA-019 has the following classifications:

Division: Cyanophyta

Class: Cyanophyceae

Order: Oscillatoriales

Family: Pseudanabaenaceae

Genus: Limnothrix

\section{Molecular identification Isolates of Microalgae}

Isolates of microalgae which has seen a need to identify the molecular morphology to see the kinship of the species. Identification of molecular generally consist of DNA extraction, amplification by PCR using 18S rDNA of eukaryotic microalgae and 16S rDNA primer for prokaryotic microalgae electrophoresis followed by PCR product purification and sequencing. 


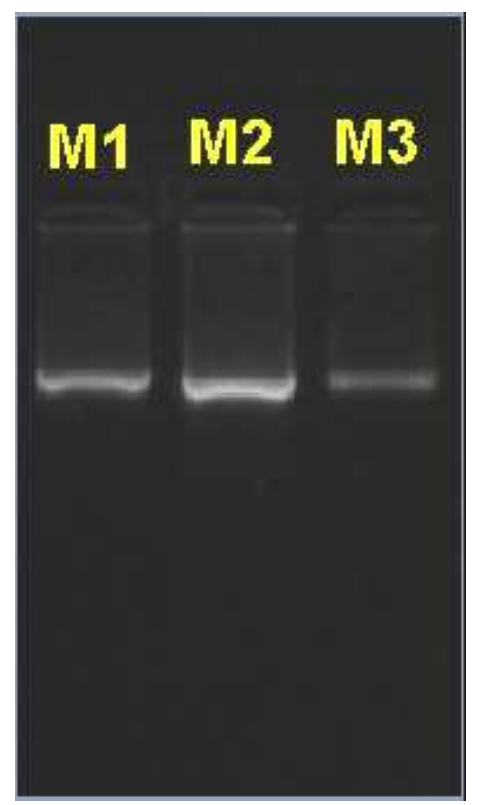

Figure 4. electropherogram of the extracted DNA isolates microalgae (M1 = AUMA-020, M2 = AUMA-023 and M3 = AUMA-019)

The results of the DNA fragment isolation of each isolate microalgae shown in Figure 4. From the figure seen AUMA-020 isolates and isolates AUMA-023 provides clear DNA fragment while isolates AUMA-019 is quite obvious but enough for amplification by PCR. All three isolates had purely because there is only one DNA bands.

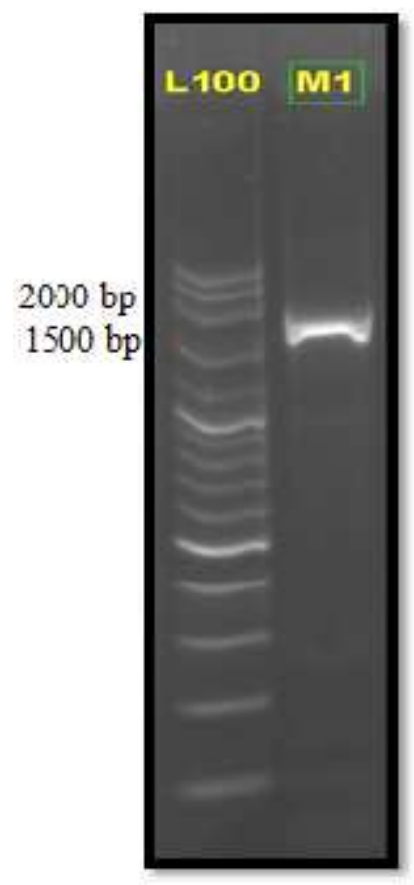

Figure 5a. Electropherogram results of $18 S$ rDNA PCR isolates AUMA-020

Identification of species of microalgae can be done by rDNA SSU and LSU rDNA. Regional D1-D2 LSU rDNA has the potential to be used in the taxonomy. This area can be amplified with universal primers, show the diversity and suitable to distinguish species with close kinship [21] as well as areas D1-D2 LSU rDNA is easily amplified and determined. In addition, the LSU rDNA seems to be more informative than SSU rDNA. According to research Soylu, et.al (2010), a species of microalgae have been determined based on the SSU rDNA (18 S rDNA) that Scenedesmus subspicatus (98\%) and Desmodesmus sp. (100\%) based on analysis philogenetik, but morphologically not belong to the two species [22]. 


\section{Isolates AUMA-020}

Based on observations with an optical microscope to isolate morphology AUMA-020 can be concluded that the isolated AUMA-020 is a eukaryotic microalgae. Primers used in the identification of biomolecular species is a universal primer 18S rDNA. Figure $5(\mathrm{a}$ and $\mathrm{b}$ ) displaying electropherogram PCR results and the results of BLAST (Basic Local Alignment Search Tool) isolates AUMA-020.

\begin{tabular}{|c|c|c|c|c|c|c|}
\hline \multicolumn{7}{|l|}{ Select All None Selected:0 } \\
\hline \multicolumn{7}{|l|}{ 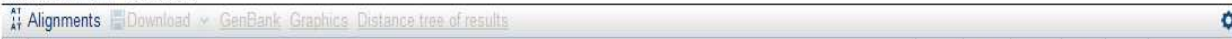 } \\
\hline Description & $\begin{array}{l}\text { Max } \\
\text { score }\end{array}$ & $\begin{array}{l}\text { Total } \\
\text { score }\end{array}$ & $\begin{array}{l}\text { Query } \\
\text { cover }\end{array}$ & $\begin{array}{c}E \\
\text { value }\end{array}$ & Ident & Accession \\
\hline [1 Acutodesmus sp. KNUA038 18 S ribosomal RNA gene, partial sequence & 3061 & 3061 & $100 \%$ & 0.0 & $99 \%$ & KT883908.1 \\
\hline Acutodesmus obliquus genes for $18 \mathrm{~S}$ rRNA. ITS1, $5.8 \mathrm{~S}$ rRNA, ITS2, 28S rRNA, partial and complete sequence, strain: GS3e & 3061 & 3061 & $100 \%$ & 0.0 & $99 \%$ & AB917118.1 \\
\hline U Scenedesmaceae Sp. Tow 9/21 P-1w $18 \mathrm{~S}$ ribosomal RNA qene, partial sequence & 3061 & 3061 & $100 \%$ & 0.0 & $99 \%$ & AY197641.1. \\
\hline I Scenedesmus deserticola isolate BCP.YPGChar $18 S$ ribosomal RNA gene, partial sequence & 3061 & 3061 & $100 \%$ & 0.0 & $99 \%$ & AY510463.1 \\
\hline SCenedesmus deserticola isolate BCP-EM2-VF3 18 S ribosomal RNA gene, partial sequence & 3061 & 3061 & $100 \%$ & 0.0 & $99 \%$ & AY510461.1 \\
\hline IS Scenedesmus deserticola isolate BCP-HAF2-VF10 18 S ribosomal RNA gene, partial sequence & 3057 & 3057 & $100 \%$ & 0.0 & $99 \%$ & Av510464.1. \\
\hline 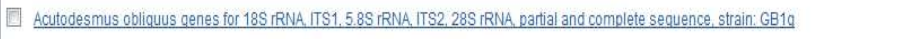 & 3055 & 3055 & $100 \%$ & 0.0 & $99 \%$ & AB917101.1 \\
\hline Acutodesmus obliquus genes for $18 \mathrm{~S}$ rRNA ITS1, $5.8 \mathrm{~S}$ IRNA ITS2.28S rRNA, partial and complete sequence, strain: GB1e & 3055 & 3055 & $100 \%$ & 0.0 & $99 \%$ & AB917100.1 \\
\hline (1) Acutodesmus obliquus isolate D22-6-2B $18 \mathrm{~S}$ ribosomal RNA gene, partial sequence & 3055 & 3055 & $100 \%$ & 0.0 & $99 \%$ & KF144164.1 \\
\hline I Acutodesmus obliquus $18 \mathrm{~S}$ ribosomal RNA qene and internal transcribed spacer 1 , partial sequence & 3055 & 3055 & $100 \%$ & 0.0 & $99 \%$ & $\underline{\mathrm{KF} 898122.1}$ \\
\hline [1 Scenedesmus basiliensis strain ACKU 646-06 $18 \mathrm{~S}$ ribosomal RNA gene and internal transcribed spacer 1 , partial sequence & 3055 & 3055 & $100 \%$ & 0.0 & $99 \%$ & $\underline{\text { KF } 898121.1}$ \\
\hline 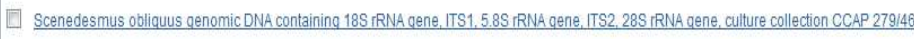 & 63055 & 3055 & $100 \%$ & 0.0 & $99 \%$ & $\underline{\text { FR } 865738.1}$ \\
\hline (1) Scenedesmus obliquus genomic DNA containing 18S IRNA gene, ITS1, 5.8S rRNA gene, ITS2, 28S IRNA gene, culture collection CCAP 276/7 & 3055 & 3055 & $100 \%$ & 0.0 & $99 \%$ & $\underline{F R 865737.1}$ \\
\hline Scenedesmus obliquus genomic DNA containina 18S rRNA gene, ITS1, 5.8S TRNA gene, ITS2, 28S TRNA gene, culture collection CCAP $276 / 52$ & 23055 & 3055 & $100 \%$ & 0.0 & $99 \%$ & $\underline{F R 865731.1}$ \\
\hline Scenedesmus obliquus genomic DNA containing 18S TRNA gene, ITS1, 5.88 TRNA gene, ITS2, 28S TRNA gene, culture c & & 3055 & $100 \%$ & 0.0 & $99 \%$ & \\
\hline
\end{tabular}

Figure 5b. BLAST results of the DNA sequences of isolates AUMA-020 


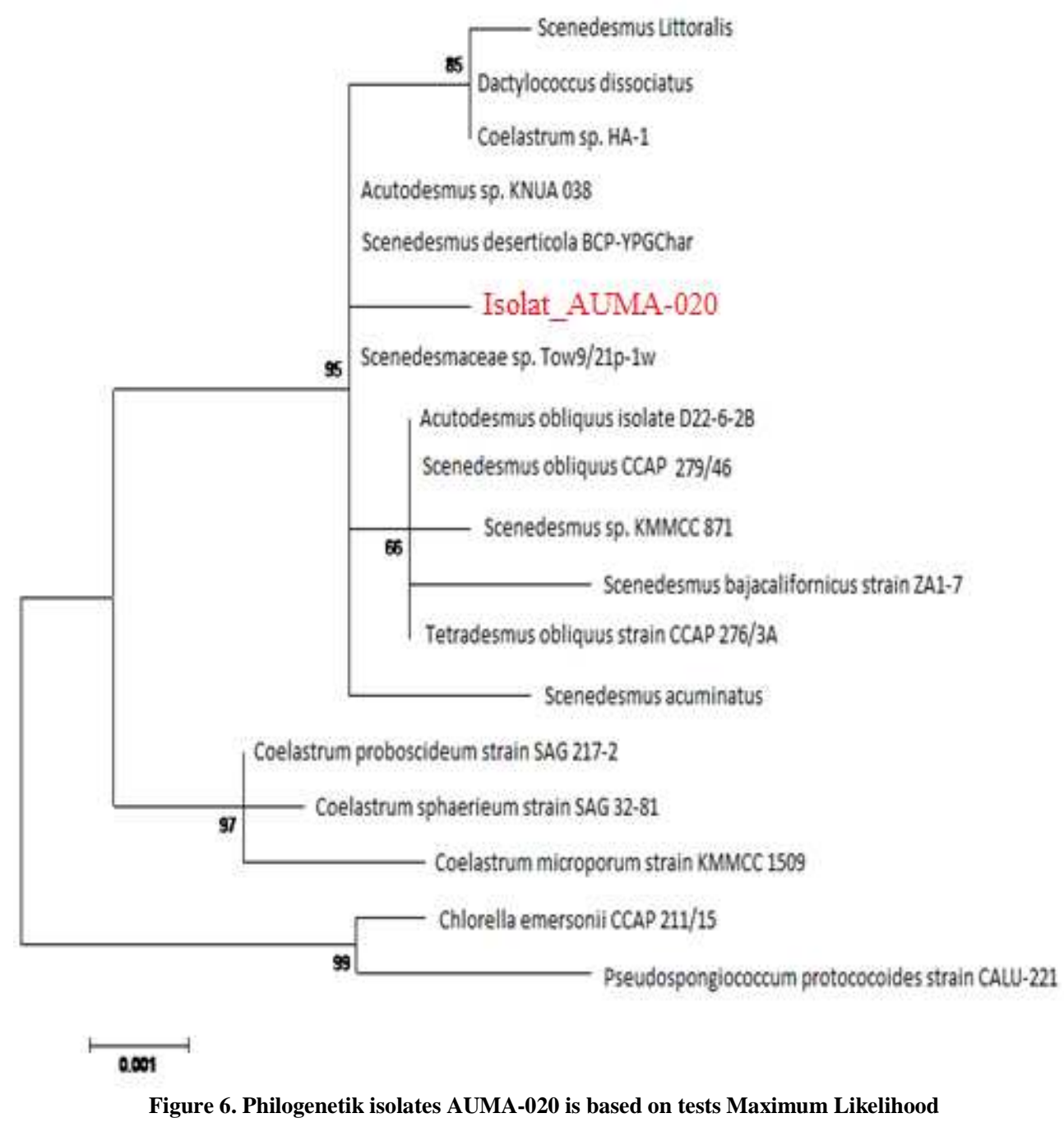

Based on the image 5a, the result of amplification of genomic DNA isolates AUMA-020 using 18S rDNA PCR with primers generate a specific DNA bands and the intensity is relatively thick. After sequencing of 18S rDNA gene fragment has the nucleotide sequence of 1670 base pairs. Determining the species isolates AUMA-020 by comparing the sequences derived from these data to the NCBI Gene Bank BLAST analysis. The results shown in Figure 5b.

From Figure 5b looks isolates AUMA-020 has a close kinship with Acutodesmus sp. KNUA 038, Scenedesmaceae sp. Tow9 / 21 p-1w and Scenedesmus deserticola BCP-YPGChar the query cover 100\% with e-value of 0.0. Similarity level of $99 \%$ due to the three species has a base length is longer than isolates AUMA-020.

Based on Maximum Likelihood test philogenetik in Figure 6 using P-distance MEGA6.06 analysis, isolates AUMA020 has a close kinship with Scenedesmus deserticola BCP-YPGhar, Acutodesmus sp. KNUA 038 and Scenedesmaceae sp. Tow $9 / 21 \mathrm{P}-1 \mathrm{w}$ by $95 \%$ with a distance of 0.001 and 0.001 standard error.

\section{Isolat AUMA-023}

Isolates auma-023 is mikroalga prokaryotic based on identification morphology so primary used is primary $16 \mathrm{~s}$ rrna.Figure 7 ( $\mathrm{a}$ and $\mathrm{b}$ ) showing elektroforegram the results of pcr and results of the blast isolates auma- 023 . 


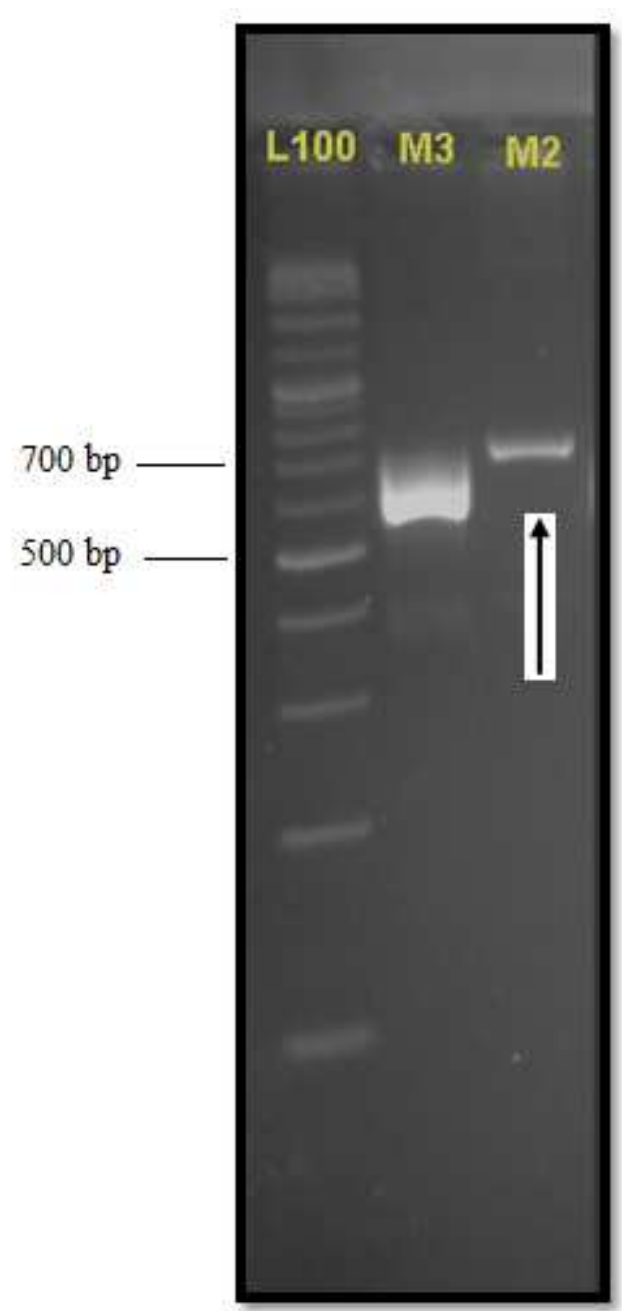

Pictures 7a. Elektroforegram results PCR 16S rDNA isolates AUMA-023

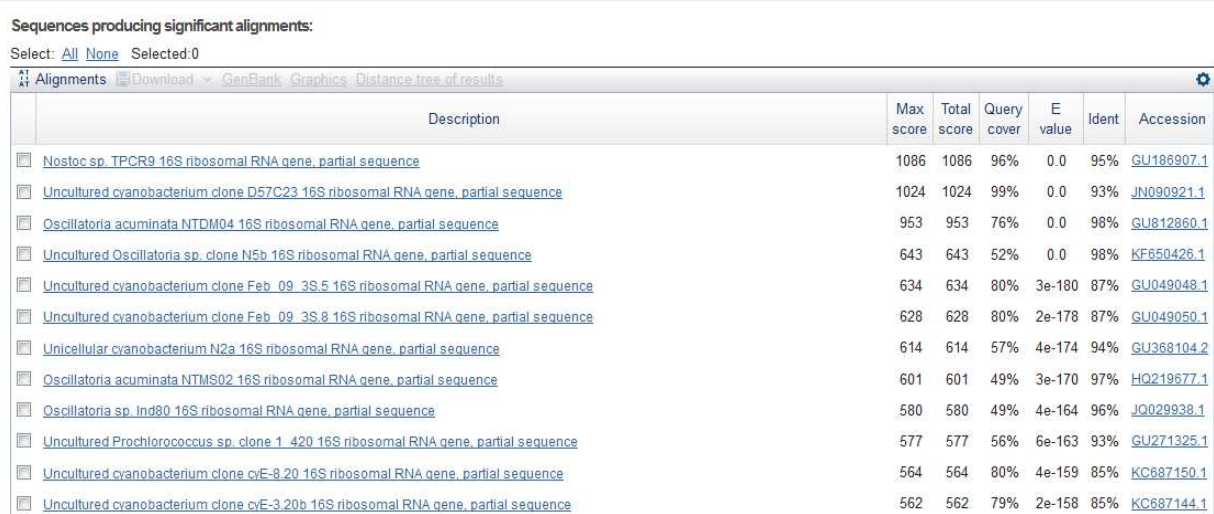

Figure 7b. BLAST results of the DNA sequences of isolates AUMA-023

Genomic DNA isolates AUMA-023 in amplification by PCR using 16S rDNA. DNA electrophoresis results showed isolates AUMA-023 with an intensity that is thick enough. BLAST analysis of the DNA sequences of isolates AUMA-023 contained in Figure 7b. After sequencing the 16S rDNA gene fragment having the nucleotide sequence of $705 \mathrm{bp}$. Based on the results of BLAST isolates AUMA-023 has a resemblance to the E-value 0 with Nostoc sp. TPCR9 96\%, Uncultured cyanobacterium clone D57C23 90\%, Oscillatoria acuminate NTDM04 $98 \%$ and Uncultured Oscillatoria sp. $98 \%$.

Based on phylogenetic trees by maximum likelihood test in figure 8, isolate AUMA-023 has a similarity of $100 \%$ by the Uncultured cyanobacterium D57C23 clone which has a base length of 705 bp equal to isolate AUMA-023. 


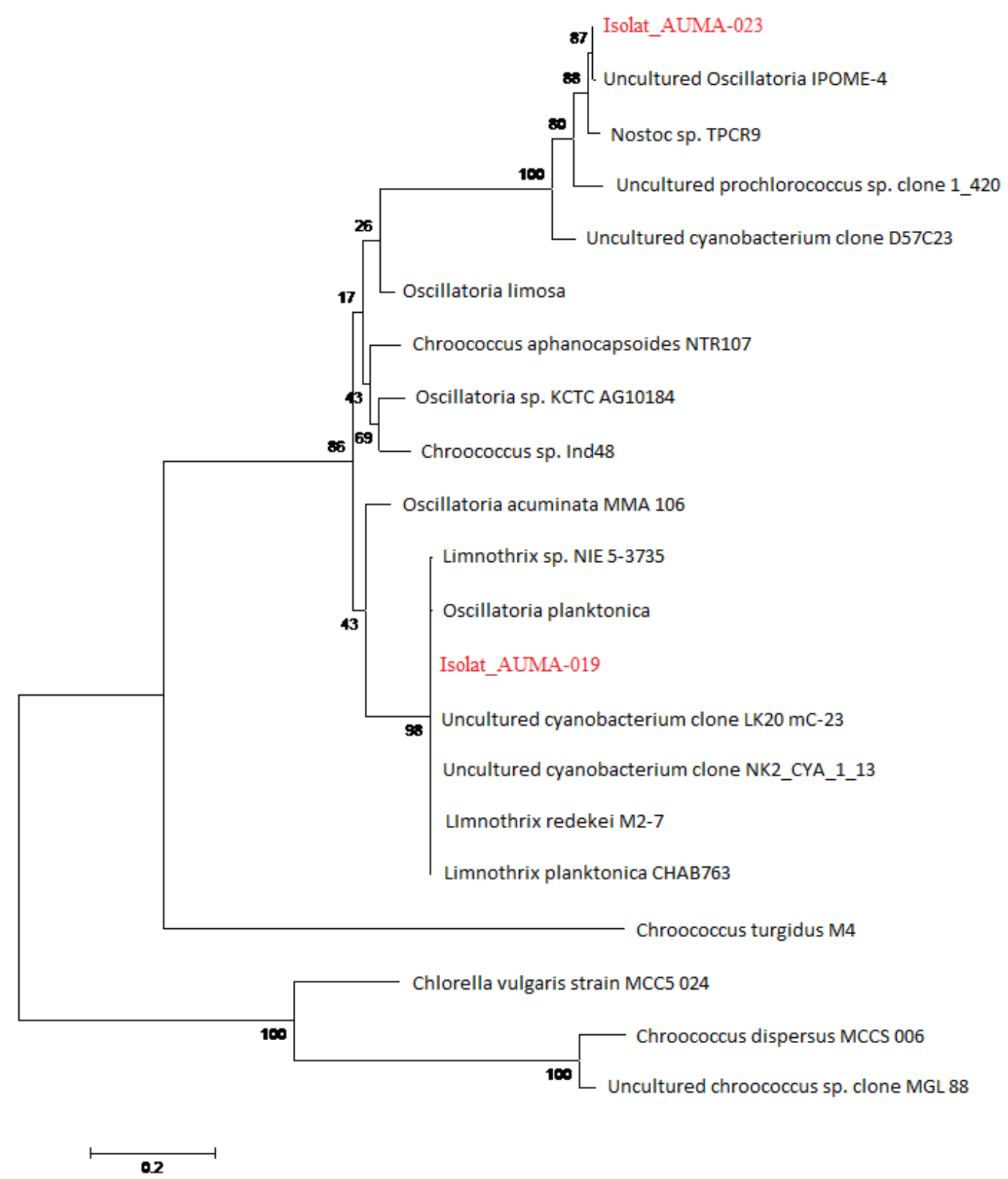

Figure 8. Phylogenetic isolates AUMA-023 and AUMA -019 is based on tests Maximum Likelihood.

Isolat AUMA-019

DNA isolates AUMA-019 is also in amplification using PCR with primers 16S rRNA. Figure 11 (a and b) displaying electropherogram PCR results and the results of BLAST isolates AUMA-019. 


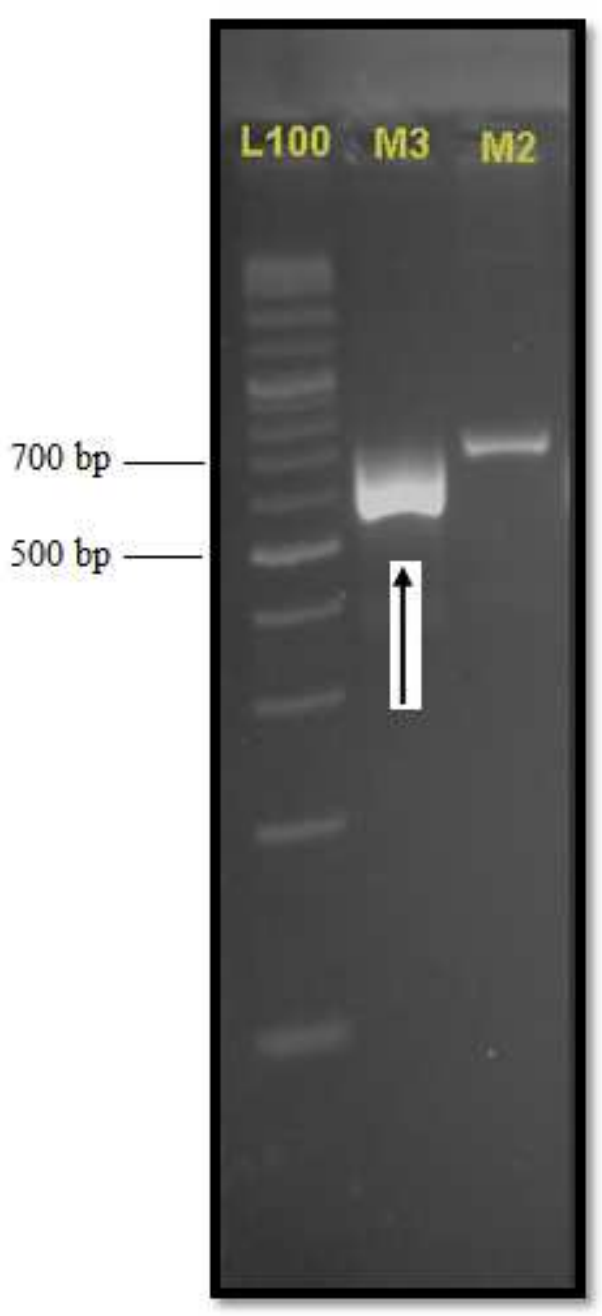

Figure 9a. Electropherogram results of 16S rDNA PCR isolates AUMA-019

\begin{tabular}{|c|c|c|c|c|c|c|}
\hline \multicolumn{7}{|l|}{ Sequences producing significant alignments: } \\
\hline Ait Alignments & & & & & & \\
\hline Description & $\begin{array}{l}\text { Max } \\
\text { score }\end{array}$ & $\begin{array}{l}\text { Total } \\
\text { score }\end{array}$ & $\begin{array}{l}\text { Query } \\
\text { cover }\end{array}$ & \begin{tabular}{|l|l} 
value \\
\end{tabular} & Ident & Accession \\
\hline 10 Limnothrix planitonica KLL-C001 clone a $16 S$ r ribosomal RNA gene, partial sequence; and $16 \mathrm{~S}-23 \mathrm{~S}$ ribosoma I RNA intergenic spacer and IRN. & ve 1164 & 1164 & $100 \%$ & 60.0 & $99 \%$ & KP726241.1 \\
\hline 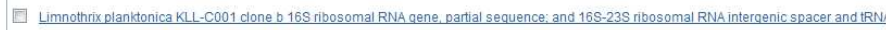 & 1164 & 1164 & $100 \%$ & 60.0 & $99 \%$ & KP726240.1 \\
\hline 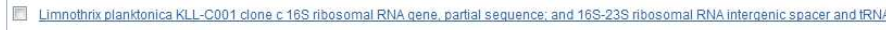 & Ne 1164 & 1164 & $100 \%$ & 600 & $99 \%$ & KP726239.1 \\
\hline 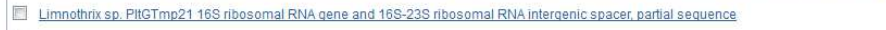 & 1164 & 1164 & $100 \%$ & 60.0 & $99 \%$ & KM438179.1 \\
\hline (Limnothrix sp. NIES.-3735 aene for 16 S ribosomal RNA, partial sequence & 1164 & 1164 & $100 \%$ & 60.0 & $99 \%$ & $\underline{L} \mathbf{C 0 3 7 4 5 0 . 1}$ \\
\hline Limnothrix sp. PUPCCC 116.216 S ribosomal RNA gene, partial sequence & 1164 & 1164 & $100 \%$ & 60.0 & $99 \%$ & KJ705099.1 \\
\hline L Limnothrix sp. NQAFF 306 16 S ribosomal RNA gene, partial sequence & 1164 & 1164 & $100 \%$ & 60.0 & $99 \%$ & KF006345.1 \\
\hline$\square$ Uncultured bacterium clone Palmetto 216216 S ribosomal RNA gene, partial sequence & 1164 & 1164 & $100 \%$ & 60.0 & $99 \%$ & $\underline{\mathrm{Jx} 521664.1}$ \\
\hline Uncultured bacterium clone Palmetto 11816 S ribosomal RNA gene, partial sequence & 1164 & 1164 & $100 \%$ & 60.0 & $99 \%$ & $\underline{\mathrm{JX521616.1}}$ \\
\hline 口 Limnothrix sp. CENA545 16 S ribosomal RNA gene, partial sequence & 1164 & 1164 & $100 \%$ & 60.0 & $99 \%$ & $\mathrm{KF} 246506.1$ \\
\hline (1) Limnothrix plankitonica CHAB76316S ribosomal RNA gene, partial sequence & 1164 & 1164 & $100 \%$ & 60.0 & $99 \%$ & $\underline{\mathrm{J} 0004026.2}$ \\
\hline 口 Limnothrix planitonica CHAB756 16 S ribosomial RNA gene, partial sequence & 1164 & 1164 & $100 \%$ & 60.0 & $99 \%$ & $\underline{\mathbf{J} 0004024.2}$ \\
\hline I Limnothrix plankitonica CHAB751 16S ribosomal RNA gene, partial sequence & 1164 & 1164 & $100 \%$ & 60.0 & $99 \%$ & $\underline{j 0004022.2}$ \\
\hline 10 Limnothrix planitonica CHAB709 16 S ribosomal RNA gene, partial sequence & 1164 & 1164 & $100 \%$ & 60.0 & $99 \%$ & $\underline{J 0004021.2}$ \\
\hline (1) Limnothrix redekei 2LT25S01 partial 16S rRNA gene & 1164 & 1164 & $100 \%$ & 60.0 & $99 \%$ & FM177493.1 \\
\hline Uncultured bacterium clone DP10.3.30 16S ribosomal RNA gene, partial sequ & 1164 & 1164 & $100 \%$ & 60.0 & $99 \%$ & EJ612381.1 \\
\hline
\end{tabular}

Figure 9b. BLAST results of the DNA sequences of isolates AUMA-019

Based on the results of amplification and sequencing of 16S ribosomal DNA gene fragments are 633 bp partial sequence of nucleotides. DNA bands resulting in amplification of genomic DNA isolates AUMA-019 shows the intensity of a relatively thick (Figure 9a). After electrophoresis of PCR products, followed by purification and sequencing the DNA sequences of isolates obtained AUMA-019. BLAST analysis of the DNA sequences of isolates AUMA-019 is shown in Figure 9b. The results of the analysis illustrates that isolates AUMA-019 has similarities with Limnothrix planktonica CHAB763, Limnothrix sp. NIES-3735, Limnothrix redekei M2-7, Uncultured 
cyanobacterium clone LK20 mC-23 and Uncultured cyanobacterium clone NK2_CYA_1_13. All strains showed the same similarity in the amount of $99 \%$ to $100 \%$ cover query and e-value 0.0 .

Judging from the phylogenetic tree figure 8, isolate AUMA-019 has a similarity of $98 \%$ with Limnothrix redekei M2-7, Uncultured cyanobacterium clone LK20 mC-23 and Uncultured cyanobacterium clone NK2_CYA_1_13. All three strains have base pair same for isolates but its isolates longer than the AUMA-019.

$2 \%$ difference could be said isolates AUMA-019 is a new species that does not exist in the data bank of genes. Judging from the morphology and based tree philogenetik, isolates AUMA-019 has a resemblance to the genus Limnothrix.

\section{CONCLUSION}

From the research that has been done can be concluded that the type isolates of microalgae that can be isolated from Maninjau Lake West Sumatra are the type Scenedesmus (code isolates AUMA-020) with a percent similarity of 95\%, Uncultured cyanobacterium (code isolates AUMA-023) with a percent similarity of $80 \%$ and type Limnothrix (code isolates AUMA-019) has a percent similarity of $98 \%$ based on data gene Bank blast and the results of the phylogenetic tree.

\section{REFERENCES}

[1] Levy, M, 2008. Encyclopedia Britannica, Inc,

[2] Mutanda, T, 2013. CRC press by Taylor \& Francis Group.

[3] Pelczar, M.J. 1986. Dasar-Dasar Mikrobiologi, UI-Press: Jakarta, (1986)

[4] Kwalk, J.H.,Baek,S.H., Woo,Y., Han,J.K., Kim,B.G., Kim,O.Y. and Lee,J.H. 2012. Nutrition Journal: 11 (53).

[5] Wen, Zhiyou, 2009, Virginia Tech.

[6] Luo,X., Su,p., Zhang,W. 2015. Marine Drugs, 13:p. 4231-4254.

[7] Bellinger, E.G and Sigee, D.C. 2010. JohnWilley \& Sons, Ltd,

[8] Barsanti, L. and Gualtieri, P. 2006. CRC Press Taylor \& Francis Group.

[9] Selvarajan, R., Felfoldi, T., Tauber, T., and Sanniyasi, E. 2015. Energies, 8: p. 7502-7521.

[10] Yang, X., Liu, P., Hao, Z., Shi, J., and Zhang, S. 2012. BioResources, 7(1): p. 686-695.

[11] Madhumathi, V, Deepa, P., Jeyachandran, S., Manoharan, C, and Vijayakumar, S. 2011. Journal of Microbiological Research, 2(3):p. 213-216.

[12] Shanab.RAI, Matter.IA, Kim.SN, Oh.YK, Choi.J, Jeon.BH. 2011. Biomass and bioenergy. 35: 3079-3085.

[13] Kaurat, S. Sarkar, M. Srivastava, RB. Gogoi, HK. Kalita, MC. 2012. New Biotechnology, 29(3): 332-344.

[14] Moro,C.V. Crouzet,O. Rasconi,S. Thouvenot,A. Coffe,G. Batisson,I. Bohatier,J, 2009. Applied and Environmental Microbiology, 75(17): 5729-5733.

[15]Duong, V.T., Liu, Y., Nowak, E., and Schenk , P.M. 2012. Energies, 5:p. 1835-1849.

[16] Vuuren, S.J., Taylor, J., Ginkel, C., and Gerber, A. 2006. School of Environmental Sciences and Development.

[17] Partensky, F., Hess, W.R., and Vaulot, D., Prochlorococcus, 1999. Microbiology and Molecular Biology Reviews, 63(1): p. 106-127.

[18] Goericke, R., and Repeta, D.J. 1992. Limnol. Oceanorg, 37(2): p. 425-433.

[19] Gantar, M., Simovic, D., Djilas, S., Gonzzales, W.W., and Miksovska, J. 2012. Journal Biothecnol. 159(1-2):p. 21-26.

[20] Sekatresna, W., Dharma, A., Zein, R., and Chaidir, Z. 2016. Der Pharma Chemica, 8(12):p. 110-117.

[21] Sonneberg, R., Nolte, A.W., and Tautz, D. 2007. Frontiers in Zoology: p. 1-12.

[22] Soylu, E.N., and Gonulol, Turk.J.Biol, 36:p. 247-254 